\title{
Construction of a Composite Hospital Admission Index using the Aggregated Weights of Criteria
}

\author{
(Pembinaan Komposit Indeks Kemasukan Hospital Menggunakan Pemberat Terkumpul Kriteria)
}

\author{
Nor Hasliza Mat Desa* Abdul Aziz Jemain \& MAZnah Mat Kasim
}

\begin{abstract}
The issue of age difference in hospital admission should be given special attention since it affects the structure of hospital care and treatments. Patients of different age groups should be given different priority in service provision. Due to crucial time and limited resources, healthcare managers need to make wise decisions in identifying priorities in age of admission. This paper aimed to propose a construction of a daily composite hospital admission index (CHAI) as an indicator that captures relevant information about the overall performance of hospital admission over time. It involves five different age groups of total patients admitted to seven major public hospitals in the Klang Valley, Malaysia for respiratory and cardiovascular diseases for a period of three years, 2008 - 2010. The criteria weights were predetermined by aggregating the subjective weight based on rank ordered centroid (ROC) method and objective weight based on entropy - kernel method. The highest and lowest scores of CHAI were marked, while the groups of patients were prioritized according to the criteria weight ranking orders.
\end{abstract}

Keywords: Aggregated weight; composite index; entropy; objective and subjective weights

\section{ABSTRAK}

Isu perbezaan umur pesakit bagi kemasukan ke hospital perlu diberi perhatian sewajarnya kerana ia memberi kesan kepada struktur rawatan dan penjagaan di hospital. Pesakit daripada kumpulan umur yang berlainan perlu diberikan perkhidmatan dan kemudahan mengikut keutamaan yang berbeza-beza. Pada waktu yang genting dan sumber yang terhad, pihak pengurusan hospital perlu bijak membuat keputusan dalam mengenal pasti keutamaan setiap kumpulan umur pesakit yang dimasukkan ke hospital. Kertas ini mencadangkan pembinaan komposit indeks kemasukan hospital harian (CHAI) sebagai penunjuk yang memberikan maklumat mengenai prestasi keseluruhan kemasukan hospital dari masa ke masa. Ia melibatkan lima kriteria atau kumpulan umur yang berbeza daripada jumlah keseluruhan pesakit yang dimasukkan ke tujuh hospital awam utama di sekitar Lembah Klang, Malaysia bagi penyakit pernafasan dan kardiovaskular dalam tempoh tiga tahun, 2008 - 2010. Pemberat bagi setiap kriteria ditentukan dengan menggabungkan pemberat subjektif berasaskan kaedah sentroid tertib pangkat (ROC) dan pemberat objektif berasaskan entropi-kernel. Skor tertinggi dan terendah CHAI boleh ditentukan, manakala kumpulan pesakit diutamakan mengikut urutan kedudukan pemberat kriteria.

Kata kunci: Entropi; indeks komposit; pemberat objektif dan subjektif; pemberat terkumpul

\section{INTRODUCTION}

As the main component of a healthcare system, hospital plays an important role in developing the healthcare system and ensuring high quality service in community and global development. Worldwide, hospital admissions indicate a continuous increase in recent years. In Malaysia, for the period of 2000-2009, the number of hospital admissions has increased approximately $37.6 \%$ to over 2 million people in 2009 compared with around 1.5 million people in 2000 (Ministry of Health Malaysia 2009). This phenomenon has contributed to future financial cost in hospitals and national care budgets (Bottle et al. 2006; Caley \& Sidhu 2010) and has led to some concerns about its impact on health care systems. In particular, the issue of age difference in hospital admission should be given a special attention since it affects the structure of hospital care and treatments. Patients of different age groups should be prioritized differently in service provision. Due to crucial time and limited resources such as equipment, staffs, beds and drugs, healthcare professionals and managers need to make wise decisions appertaining hospital admission.

In order to improve the service policy and the performance of hospital admission, the related effective measures are urgently desired by researchers, policy analysis, politicians and the general public. One way of assessing the performance of hospital admission is the development of composite indexes or indices that capture relevant information about the overall performance of hospital admission over time. It also plays an important role in identifying the trends and variation level of hospital admission. The index values lie between zero (the best admission performance) and one (the worst admission performance). Technically, composite index is a numerical or mathematical aggregation of a set of 
individual indicators that measures multi-dimensional data with different measurement units (OECD 2008).

Currently, there are rapid developments of composite index in various fields including economy, environment and technology by many national and international organizations. Examples of well-established composite index are the Human Development Index, the Townsend Index, the Technology Achievement Index, the Environmental Sustainability Index and the Malaysia Quality of Index (Nik Azman 2010; Saisana \& Tarantola 2002). However, the development of a composite index is relatively new and limited in context of hospital admission (Martin et al. 2012). Therefore, the aim of this study was to develop a composite hospital admission index (CHAI) for the Klang Valley, Malaysia which covers a 3 year period, 2008-2010. This area is chosen due to the fact that its location is in heavily industrialized urban area in the Peninsular Malaysia (Afroz et al. 2007). Daily count of hospital admissions data are stratified into five age groups: $\mathrm{G}_{1}$ (less than 7 years), $\mathrm{G}_{2}$ (7-15 years), $\mathrm{G}_{3}$ (16-40 years), $\mathrm{G}_{4}$ (41-54 years) and $\mathrm{G}_{5}$ (over 55 years). The first essential step in constructing composite hospital admission index is the determination of criteria weight of each age group. Weights are important measure in gauging the relative importance or influence of each age group towards the final index score. Multi-criteria decision making (MCDM) weighting method has recently gained much popularity in composite index construction. MCDM is a well-established technique that could help decision makers to evaluate and rank a finite set of alternatives with respects to multiple criteria (Zeleny 1982).

In this study, the criteria weights are obtained by aggregating the subjective and objective weight obtained through two MCDM methods, respectively. Besides using the weights in the CHAI construction, these weights were used as references to prioritize the five different age groups of patients admitted to hospitals. The subjective weight and objective weight relate to different aspects. Specifically, the subjective weight requires experts' opinion to evaluate the relative importance of the criteria and the objective weight is determined based on intrinsic information contained in so called performance matrix or decision matrix. This study also investigates the day-to-day and month-to-month variations in the resulted CHAI.

The next section describes the data and the study area, the proposed aggregated weights for each group age and the construction of CHAI for the selected data and study area. Then it is followed by results, discussion and conclusion of the study.

\section{MATERIALS AND METHODS}

The Klang Valley is a basin located on the west coast of the Peninsular Malaysia, and is surrounded by highlands of over $1500 \mathrm{~m}$ altitude to the east and by the Straits of Malacca to the west. The area of the Klang Valley is approximately $2832 \mathrm{~km}^{2}$, comprising Kuala Lumpur and its suburbs, as well as the adjoining cities and towns within the state of Selangor. The Klang Valley is considered to be the heartland of Malaysia's industry and commerce. Many studies have been conducted in the Klang Valley owing to its location and widespread development, which resulted in rapid urbanization, dense population and heavy industrial activities in Peninsular Malaysia (Dominick et al. 2012; Mahiyuddin et al. 2012; Omar et al. 2002).

Data of daily hospital admission records from 1 January 2008 to 31 December 2010 were obtained from the Department of Statistics, Malaysia. A total of seven major public hospitals in Klang Valley were selected for analysis in this study, namely Hospital Kuala Lumpur (HKL), Hospital Tengku Ampuan Rahimah Klang (HTAR), Hospital Kajang (HK), Hospital Selayang (HS), Hospital Sungai Buloh (HSB), Hospital Serdang (HSer) and Hospital Ampang (HA). Based upon the International Classifications of Diseases, 10th Revision (ICD-10) codes, the study focuses on hospital admission due to the respiratory disease (ICD-10 codes: J00-J99) and the cardiovascular disease (ICD-10 codes: I00-I99), of which both diseases are the top leading causes of hospital admissions in Malaysia. Data were stratified into five age groups or criteria as follows: $\mathrm{G}_{1}$ (less than 7 years), $\mathrm{G}_{2}$ ( $7-15$ years), $\mathrm{G}_{3}$ (16-40 years), $\mathrm{G}_{4}$ (41-54 years) and $\mathrm{G}_{5}$ (over 55 years).

\section{DETERMINATION OF WEIGHT}

A common practice in constructing a composite index depends on the underlying weighting and aggregation function (Zhou et al. 2010). Weights are important measure in quantifying the relative importance of criteria. In general, criteria weight can be determined by subjective, objective or combination of the two methods.

\section{SubJeCtive Method}

Subjective methods determine the criteria weights solely according the preferential judgments of decision maker(s) or expert(s) which include rank-based method and pair wise comparison method. However, the pairwise comparisons in the Analytic Hierarchy Process (AHP) method are sometime difficult and time consuming and may involve some level of inconsistency (Hermans et al. 2010). In order to tackle this problem, a simpler way to determine weights of criteria is chosen by using rank-based methods, where experts can rank the order of significance of the criteria based on their judgments. Suppose there are $n$ criteria to be evaluated, the expert(s) has to give rank on a scale of 1 to $n$, where 1 implies 'the most important' criterion, 2 -'second most important criterion', until $n$ - 'the least important criterion'. Therefore, it is important to gather expert with a broad spectrum of knowledge and experience. The selection of experts is crucial and should be done properly.

There are several methods of generating the criteria weights from the rank-order information obtained. Among 
others, it is well known that the rank order centroid (ROC) method is superior and more accurate than the other approximation methods (Ahn 2011 Barron; \& Barrett 1996) in solving multi-criteria problems. It can also be considered as a practical method in determining criteria weight because it is easier to use than the AHP method (Noh \& Lee 2003). The ROC method can assist in reducing the number of pairwise comparisons by placing the criteria in order of importance. The numerical value of each criterion is calculated according to their importance ranking, therefore there is no need for considering the consistency of the judgment on the criteria evaluated by the experts. Based on the ROC method, if there are $n$ criteria, the subjective weight for the criteria ranked in jth position is evaluated as follows,

$$
w_{j}^{\text {sub }}=\frac{1}{n} \sum_{i=j}^{n} \frac{1}{i}, \quad j=1,2, \ldots, n, \quad 0 \leq \sum_{j=1}^{n} w_{j}^{\text {sub }} \leq 1 .
$$

In this study, three experts in health care industry were asked to rank the five criteria of age of patient to be admitted to hospital from the most important to the least important criteria. All experts had more than five years of work experience in health institution. Five criteria were ranked 1 st through 5 th, then the corresponding weight for each criterion was calculated by the ROC method. For example, if $\mathrm{G}_{1}$ was ranked at 1 st priority (the most important criteria), then its weight would be:

$$
w_{1}^{s u b}=\frac{1}{5}\left(1+\frac{1}{2}+\frac{1}{3}+\frac{1}{4}+\frac{1}{5}\right)=0.4567
$$

Since a group of three experts was involved in doing rankings, the ranks given by each expert were used to calculate the weights of each criterion by ROC method. After that, the final subjective weight of each criterion was obtained by finding the mean of those weights (Maznah 2008; Maznah \& Jemain 2012).

\section{OBJECTIVE WeIGHT}

Apart from the subjective approach, the objective weight is based on intrinsic information of the data and it involves several mathematical computations without any consideration of decision maker's preference, for example the entropy method. The entropy method can be used in determining objective weight which is based on the measure of uncertainty of the information as formulated in probability theory (Hwang \& Yoon 1981).

In general, the determination of objective weight usually involves five-step process. First, decision matrix was constructed with $\mathrm{m}$ alternatives or day, $A_{i}(i=1,2 \ldots$, $m)$ against $n$ attribute or criteria of age groups, $\mathrm{G}_{j}(j=1,2 \ldots$ $n$ ) and $x_{i j}$ being the daily frequency of hospital admission across all criteria of age. The decision matrix can be concisely expressed in a matrix as follows.

$$
\begin{aligned}
& \begin{array}{lllll}
\mathrm{G}_{1} & \mathrm{G}_{2} & \ldots & \mathrm{G}_{n}
\end{array} \\
& X=\begin{array}{c}
A_{1} \\
A_{2} \\
\ldots \\
A_{m}
\end{array} \mid\left[\begin{array}{cccc}
x_{11} & x_{12} & \ldots & x_{1 n} \\
x_{21} & x_{22} & \ldots & x_{2 n} \\
\ldots & \ldots & \ldots & \ldots \\
x_{m 1} & x_{m 2} & \ldots & x_{m n}
\end{array}\right] .
\end{aligned}
$$

Second, normalization technique was used to transform the various criteria scale into a comparable scale. The normalized score, $r_{i j}$ can be computed by:

$$
r_{i j}=\frac{x_{i j}-x_{\min }}{x_{\max }-x_{\min }} .
$$

where $x_{\max }$ and $x_{\min }$ represent maximum and minimum frequency for each criterion, respectively, with the range of $r_{i j}$ is between 0 and 1 .

Third, the entropy values $E_{j}$ were defined as:

$$
E_{j}=-\frac{1}{\ln m} \sum_{j=1}^{m}\left(\frac{f_{i j}}{\sum_{j=1}^{m} f_{i j}}\right) \ln \left(\frac{f_{i j}}{\sum_{j=1}^{m} f_{i j}}\right),
$$

where $f_{i j}=\frac{1}{n h} \sum_{j=1}^{m} K\left(x_{i j}-x_{j}\right) / h$ with $f_{i j}$ represent the density estimation with Gaussian kernel (Silverman 1986), $K(t)=\frac{1}{\sqrt{2 \pi}} \exp \left(-t^{2} / 2\right)$ and $h=1.06$ (standard deviation) $n^{-1 / 5}$. Fourth, the degree of divergence $d_{j}$ of the intrinsic information in each age criteria is calculated as $d_{j}=1-E$ where the values of $d_{j}$ represent the inherent contrast of intensity of $j$ th criteria. Therefore, the objective weight for each criterion was obtained as:

$$
w_{j}^{o b j}=\frac{d_{j}}{\sum_{j=1}^{n} d_{j}}, \quad j=1,2, \ldots, n, \quad 0 \leq \sum_{j=1}^{n} w_{j}^{o b j} \leq 1 .
$$

\section{AGGREGATED WEIGHT}

In this study, the aggregated weight is proposed in which it combines the subjective and objective weights. Aggregation of weights refers to the process of integrating the subjective weight based on expert opinion and objective weight based on data information. The proposed aggregation method provides a new way to reflect both weights, which overcomes the disadvantages of these two individual approaches. The aggregated weight of criteria is calculated as follows:

$$
w_{j}=\frac{w_{j}^{s u b} \cdot w_{j}^{o b j}}{\sum_{j=1}^{n} w_{j}^{s u b} \cdot w_{j}^{o b j}}, \quad j=1,2, \ldots, n, \quad 0 \leq \sum_{j=1}^{n} w_{j} \leq 1
$$




\section{CONSTRUCTING A CHAI}

The CHAI score results from the sum of the products of the normalized scores with the corresponding aggregated weights of criteria. The CHAI score can be written mathematically as follows.

$$
\mathrm{CHAI}_{i}=w_{1} r_{i 1}+w_{2} r_{i 2}+\ldots+w_{n} r_{i n}=\sum_{j=1}^{n} w_{j} r_{i j}
$$

where $\mathrm{CHAI}_{i}=$ CHAI score for day $i=1,2, \ldots, m, w_{j}$ is the aggregated weight of criteria (age group), $j=1,2, \ldots, n$; and $r_{i j}$ is the normalized score of hospital admission for day $i, i=1,2, \ldots, m$ with respect to criteria $j$.

The CHAI score has ranges from 0 to 1 , with a lower CHAI score corresponding to a lower hospital admission and vice versa. This means that lower index represents a good hospital admission performance while higher index refers to a bad hospital admission performance. All analyses were performed using R statistical software version 2.13.2 (R Development Core Team 2009).

\section{RESULTS AND DISCUSSION}

During the three-year study period between 2008 and 2010, a total of 172573 patients for respiratory and cardiovascular diseases were admitted to seven major public hospitals in the Klang Valley, Malaysia with $57.7 \%$ males and $42.3 \%$ female. The median age of admitted patients was 46 years old and the inter-quartile (IQR) is 55 years old. Table 1 summarizes the descriptive statistics on daily hospital admission for five age groups or criteria over 1096 days. The average admission for $G_{1}$ is $39.03 \pm 12.15$ per day, $\mathrm{G}_{2}$ is $8.36 \pm 4.34$ per day, $\mathrm{G}_{3}$ is $20.64 \pm 8.42$ per day, $\mathrm{G}_{4}$ is $33.28 \pm 9.02$ per day and $G_{5}$ is $56.15 \pm 11.39$ per day. It can be seen there is a large difference in daily admission averages between $G_{1}$ and $G_{2}$ with the range value of 30.67 , even though these two are consecutive groups in term of age. The median values of daily admission for each group are similar to the mean values.

Following the step-by-step process as discussed previously, the aggregated weights were determined for each age criterion. It can be seen in Table 2 that Expert 1 and Expert 2 assigned the highest ranking to $G_{1}$, while Expert 3 ranked $\mathrm{G}_{4}$ as the most important criteria. All the experts have agreed that $G_{5}$ was the second most important criteria compared to the other groups. $\mathrm{G}_{2}$ and $\mathrm{G}_{4}$ were listed as the least important criteria by the experts with the ratio of $G_{2}$ to $G_{4}$ was $2: 1$. Based on the ranking given by the experts in Table 2, the subjective weights were calculated using ROC method as displayed in Table 3. The final rank of the aged groups shows that $\mathrm{G}_{1}(0.3567)$ was the most important criterion followed by $\mathrm{G}_{5}(0.2567), \mathrm{G}_{4}(0.1956)$, $\mathrm{G}_{3}(0.1122)$ and $\mathrm{G}_{2}(0.0789)$.

In contrast, the objective weights were found to give a different ranking for the criteria as appeared in column 4 and 5 of Table 4 with the highest weight indicated by $\mathrm{G}_{3}$ $(0.2308)$, while the least weight recorded by $\mathrm{G}_{4}(0.1640)$. In order to capture both subjective and objective judgments of the relative importance of the criteria, the aggregated weight was computed and the results (column 6 and 7) showed that the highest criteria weight is assigned to $G$ (0.3509) followed by $\mathrm{G}_{5}(0.2510), \mathrm{G}_{4}(0.1677), \mathrm{G}_{3}(0.1355)$ and $\mathrm{G}_{2}(0.0949)$. In comparing the rankings of the criteria, there is a similar criteria ranking between subjective and aggregated weights. More specifically, both $\mathrm{G}_{1}$ and $\mathrm{G}_{5}$ always have the top two highest weights. This implies that these two age groups should be given topmost priorities to be admitted for respiratory and circulatory diseases treatment. A large difference in weights between $G_{1}$ and $\mathrm{G}_{2}$ may be due to a large range in their daily admission averages. Furthermore, the big gap between the aggregated weights of these two groups may also be influenced by the experts' judgments as illustrated in Table 2. More

TABLE 1. Descriptive statistic for hospital admission for 5 groups of ages from 1 January 2008 to 31 December 2010

\begin{tabular}{lccccccc}
\hline Group of age & Total & Mean $\pm \mathrm{SD}$ & Minimum & $25 \%$ & Median & $75 \%$ & Maximum \\
\hline $\mathrm{G}_{1}(<7)$ & 42773 & $39.03 \pm 12.15$ & 2 & 31 & 38 & 46 & 95 \\
$\mathrm{G}_{2}(7-15)$ & 9162 & $8.36 \pm 4.34$ & 0 & 6 & 8 & 10 & 38 \\
$\mathrm{G}_{3}(16-40)$ & 22624 & $20.64 \pm 8.42$ & 2 & 15 & 20 & 24 & 77 \\
$\mathrm{G}_{4}(41-55)$ & 36471 & $33.28 \pm 9.02$ & 1 & 27 & 33 & 39 & 67 \\
$\mathrm{G}_{5}(>55)$ & 61543 & $56.15 \pm 11.39$ & 4 & 49 & 56 & 65 & 89 \\
\hline
\end{tabular}

TABLE 2. Rank evaluated by three experts for 5 groups of ages

\begin{tabular}{lccc}
\hline Group of age & Expert 1 & Expert 2 & Expert 3 \\
\hline $\mathrm{G}_{1}(<7)$ & 1 & 1 & 3 \\
$\mathrm{G}_{2}(7-15)$ & 5 & 3 & 5 \\
$\mathrm{G}_{3}(16-40)$ & 3 & 4 & 4 \\
$\mathrm{G}_{4}(41-55)$ & 4 & 5 & 1 \\
$\mathrm{G}_{5}(>55)$ & 2 & 2 & 2 \\
\hline
\end{tabular}


TABLE 3. Subjective weight for each expert, final subjective weight and the rank position

\begin{tabular}{lccccc}
\hline Group of age & $\begin{array}{c}\text { Weight } \\
\text { (Expert 1) }\end{array}$ & $\begin{array}{c}\text { Weight } \\
\text { (Expert 2) }\end{array}$ & $\begin{array}{c}\text { Weight } \\
\text { (Expert 3) }\end{array}$ & Subjective weight & Rank \\
\hline $\mathrm{G}_{1}(<7)$ & 0.4567 & 0.4567 & 0.1567 & 0.3567 & 1 \\
$\mathrm{G}_{2}(7-15)$ & 0.04 & 0.1567 & 0.04 & 0.0789 & 5 \\
$\mathrm{G}_{3}(16-40)$ & 0.1567 & 0.09 & 0.09 & 0.1122 & 4 \\
$\mathrm{G}_{4}(41-55)$ & 0.09 & 0.04 & 0.4567 & 0.1956 & 3 \\
$\mathrm{G}_{5}(>55)$ & 0.2567 & 0.2567 & 0.2567 & 0.2567 & 2 \\
\hline
\end{tabular}

TABLE 4. Subjective, objective and aggregated weight for each group

\begin{tabular}{lcccccc}
\hline Group of age & $\begin{array}{c}\text { Subjective } \\
\text { weight }\end{array}$ & $\begin{array}{c}\text { Subjective } \\
\text { rank }\end{array}$ & $\begin{array}{c}\text { Objective } \\
\text { weight }\end{array}$ & $\begin{array}{c}\text { Objective } \\
\text { rank }\end{array}$ & $\begin{array}{c}\text { Aggregated } \\
\text { weight }\end{array}$ & $\begin{array}{c}\text { Aggregated } \\
\text { rank }\end{array}$ \\
\hline $\mathrm{G}_{1}(<7)$ & 0.3567 & 1 & 0.1881 & 3 & 0.3509 & 1 \\
$\mathrm{G}_{2}(7-15)$ & 0.0789 & 5 & 0.2301 & 2 & 0.0949 & 5 \\
$\mathrm{G}_{3}(16-40)$ & 0.1122 & 4 & 0.2308 & 1 & 0.1355 & 4 \\
$\mathrm{G}_{4}(41-55)$ & 0.1956 & 3 & 0.1640 & 5 & 0.1677 & 3 \\
$\mathrm{G}_{5}(>55)$ & 0.2567 & 2 & 0.1870 & 4 & 0.251 & 2 \\
\hline
\end{tabular}

specifically, two experts ranked $\mathrm{G}_{1}$ at first priority, while two experts ranked $\mathrm{G}_{2}$ at last position.

The CHAI score has ranges from 0 (the best performance) to 1 (worst performance). In other words, the higher the CHAI score signify the greater level of hospital admission and demand greater hospital treatments. The CHAI score in Figure 1 shows an increasing trend from 1 January 2008 until 31 December 2010 with the median score of $0.4275,0.0025$ and 0.8208 are minimum and maximum scores, respectively. The CHAI score starts with a value of 0.2348 on 1st January 2008, then the score has fluctuated between a low of 0.1552 on 1st October 2008 and a peak of 0.8208 on 14th August 2009. After falling down quickly in September 2009 to a value of 0.2231 , fluctuations in the CHAI score seem to be roughly consistent from October 2009 to November 2010. However, there is a steep fall in the CHAI score at the end of December 2010.

It was also of interest to investigate the weekly and monthly variation of the CHAI scores during the entire time period. A comparison of the weekly CHAI scores over different years (2008, 2009 and 2010) is depicted in Figure 2. Overall results show a clear difference between the CHAI score on weekdays and weekends. The score is found to be consistently higher during the weekdays especially on Mondays compared to the weekends. The boxplot in Figure 3 highlighted the behavior of monthly CHAI scores. It shows that the monthly variation of CHAI scores varied across the 3 years. There is no specific pattern in specific month over the three year period, but there is a decreasing pattern of scores from months of April to June, and from October to December. In terms of yearly analysis, the fluctuations of CHAI scores between months in 2008 were low with a median score ranges from 0.3345 to 0.4118 . In 2009, the extreme high score appeared in August with minimum, maximum and median scores, 0.3653, 0.8208 and 0.6432 , respectively whereas a lower median score is

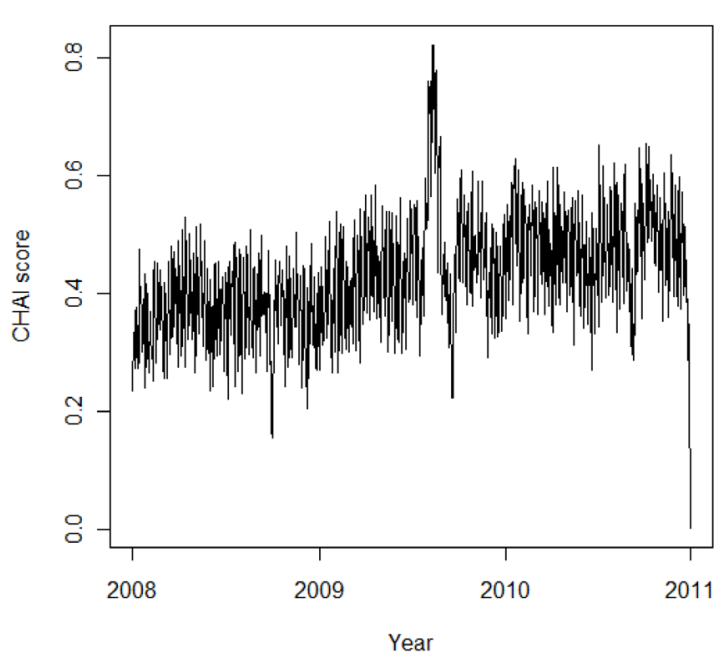

FIGURE 1.Graph of the CHAI scores from 1 January 2008 to 31 December 2010

found in September. The medians score are quite similar for all months in 2010 except for month of October which the highest median score was 0.5314 . However, there are a few extreme low scores at the end of December 2010.

This study has illustrated three key points. First of all, this study helps in identifying which age groups have the higher possibility to be admitted to respiratory and cardiovascular hospitals by exploring and determining criteria weights for five age groups using aggregated weights. The proposed weight aggregation method that integrates objective and subjective weights provides a new practical approach in human science. This approach counts both decisions and overcome the disadvantages of these two individual approaches. The proposed aggregated weights are more precise and accurately estimated as compared to a single method. As expected, the results indicated that 
(a) 2008

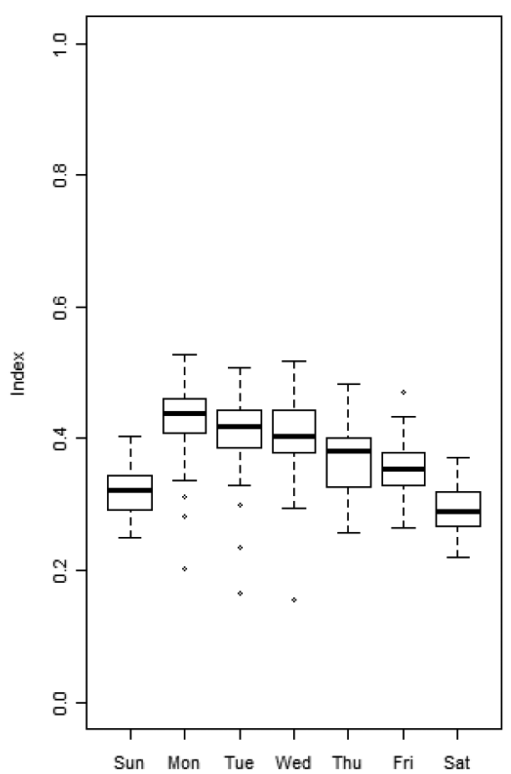

Day (b) 2009

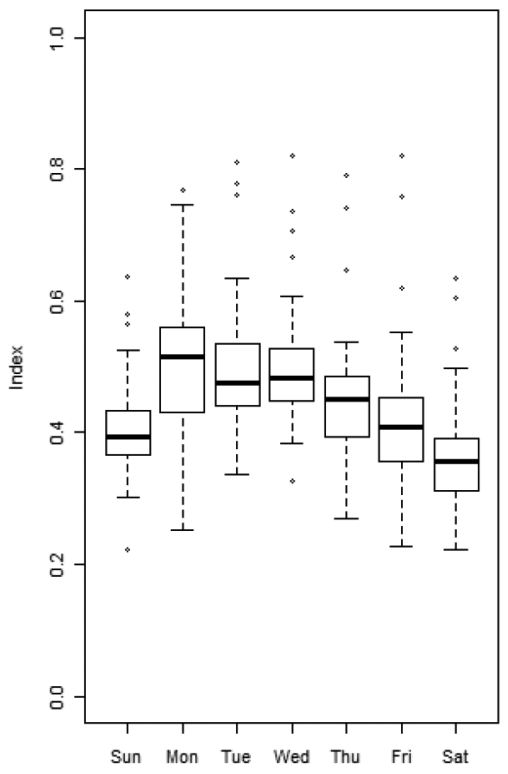

Day (c) 2010

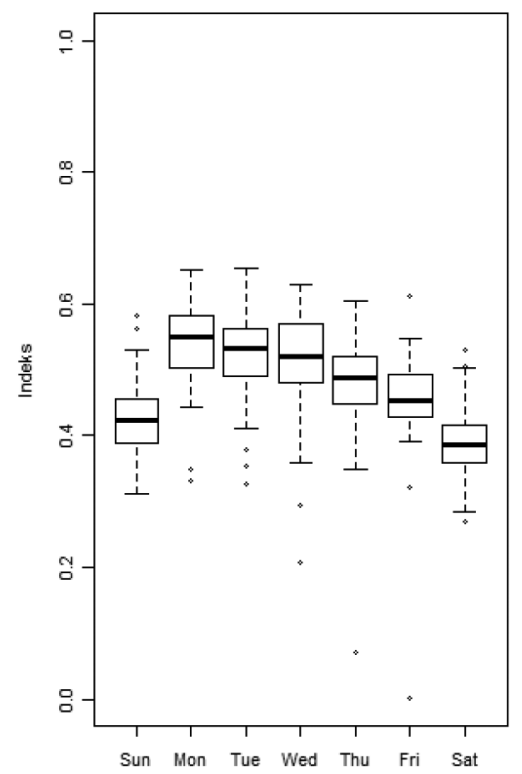

Hari

FIGURE 2. Weekly variations of the CHAI scores
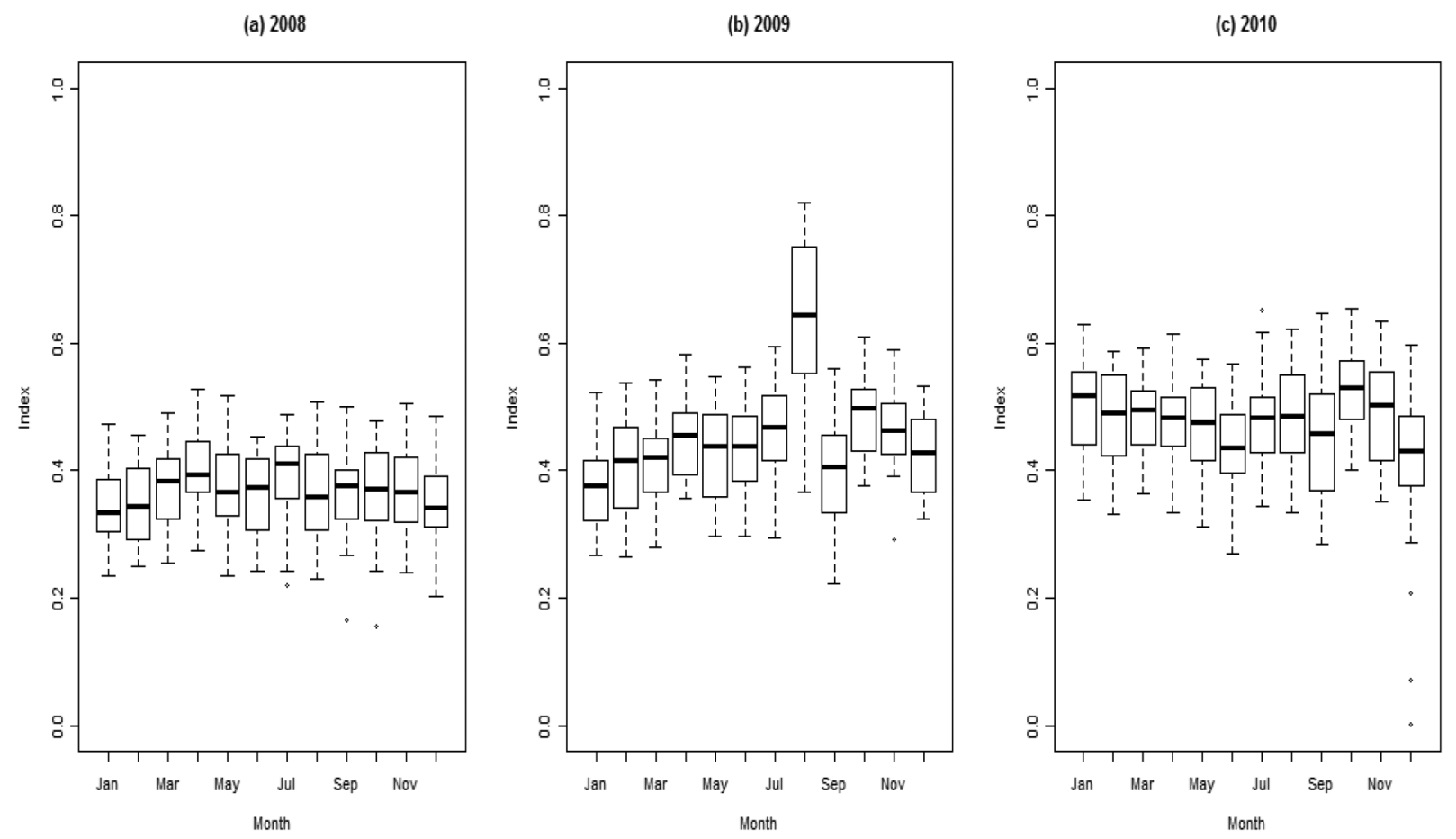

FIGURE 3. Monthly variations of the CHAI scores

group of age less than 7 years and over 55 years have to be given the highest priority to be admitted for respiratory and cardiovascular diseases treatments compared with the other age groups. This finding corroborates several previous studies that examined the risks of exposure to air pollution-related respiratory and cardiovascular diseases on hospitalization among children and elderly (Jalaluddin et al. 2006; Ostro et al. 2009). It is sensible to presume that these two age groups were particularly sensitive to air pollutant since they have very different lung function and immune systems. Therefore, healthcare professionals and general public should put more concern and special attention to these two groups.

Secondly, the CHAI score was developed as an indicator to describe the level of daily hospital admission over time. The advantage of these composite indexes is that the index 
provides a single metric that is easily interpreted for the overall hospital performance over time. The results of this study also imply that CHAI has increased significantly during the study period from 1 January 2008 to December 2010. This increasing trend needs further investigation as it may be partly due to a change in admission policies in hospital departments, improvement in record keeping and increased in public awareness in Malaysia.

Thirdly, it is also interesting to compare the weekly and seasonal variations of composite index at a different time scales. These finding can help hospital managements to provide enhanced room capacity, extra room, better patient-scheduling practices, staff capacity, and equipment availability for higher CHAI for busiest day of the week and months of admission. Analysis of daily variation reveals a clear difference between weekdays and weekends admission during the study period. Higher scores occur during the beginning on the week while the scores are lower on the weekends. It is possible that the differences between weekdays and weekends admission could be due to a lower hospital staffing levels and service availability (Hamilton et al. 2007). The association between weekend and outcomes of patients admitted is known as 'weekend effect' (Cram et al. 2004). Several recent studies have investigated the effect of weekend admission on hospital mortality and have found an increase of risk of death for weekend admission compared to those patients admitted on weekday (Aylin et al. 2010). However, further studies should be conducted to determine the relationship between weekend effects and other covariates factors so that certain proactive actions should be introduced by the hospital management in order to reduce the increase risk of death associated with weekends admission.

The highest score appeared in July, August and October where Malaysia is usually having a dry season during this period of time (Azmi et al. 2010). Many studies have shown that hospital admission for respiratory and cardiovascular is positively associated with environmental and meteorological factor such as temperature, relative humidity, and weather (Friger et al. 2006; Schwartz et al. 2004; Shao et al 2008). However, there is some evidence that both cold and hot temperature for hospital admission vary by location. For example, several recent studies conducted in North America have found that hospital admission is generally higher in warm period as compared with the cool period (Peng et al. 2005; Ren \& Tong 2006a; Stafoggia et al.2008), while studies in Asian countries have provided inconsistent result; hospital admission increased in cool months (Chena et al. 2010; Kan et al. 2008; Liang et al. 2009) and others have reported increment in warmer months (Choi et al. 2007; Yi et al. 2010).

Nonetheless, there are a few limitations in this study. A number of considerations must be taken into consideration to construct composite index in choosing the appropriate weighting method. Criteria weights can be determined objectively by several other methods such as principal component analysis, factor analysis, optimization, data envelopment analysis, neural network, equal weighting and rough set theory methods, Similarly, there are many subjective methods available to determine the criteria weight such as analytical hierarchy process and budget allocation (Hermans et al. 2008). Correspondingly the selection of experts in giving the subjective opinion is also crucial and should be well-considered since humans' judgments are influenced by experience, depth of knowledge, relative intelligence and personal involvements (Saaty 1980). Besides that, the type of evaluation methods and the understanding of methods may also affect the overall evaluation. Furthermore, the judgment and evaluation may differ due to time as well as change in social circumstances (Jackson 2001).

\section{CONCLUSION}

Our findings show that groups of age less than 7 years and over 55 years have the highest scores being admitted to hospital for respiratory and cardiovascular diseases compared with other age groups. Therefore, hospital administration should focus more on these two age groups especially in crucial time. In comparing day of week and seasonal variations, the higher CHAI scores were prevalent on weekdays especially on Mondays to Wednesdays as compared with weekends. However, there is no specific pattern in specific month over the three year period. Specifically, the higher CHAI scores appeared in July, August and October while the lower score is found in January and December. In summary, the daily CHAIs do not only guide attention on high values, but also clearly identifies opportunities for improvement through observation and knowledge sharing from other days with low CHAI. Eventually, our finding could assist decisions on care management and could improve level of awareness and knowledge particularly in relation of hospital admission to health professional and general public.

\section{ACKNOWLEDGEMENTS}

We would like to gratefully acknowledge the Institute for Medical Research (IMR), and the Department of Statistics (DOS), Malaysia for providing the data. Special thanks to Universiti Utara Malaysia, Universiti Kebangsaan Malaysia and Ministry of Education (MOE), Malaysia on their sponsorship. We also wish to thank the Director General of Health, Ministry of Health, Malaysia and the Director of the IMR for the permission to publish this paper.

\section{REFERENCES}

Afroz, R., Hassan, M.N., Awang, M. \& Ibrahim, N.A. 2007. Benefits of air quality improvement in Klang Valley Malaysia. Inter. J. Environ. Pollut. 30: 119-136.

Ahn, B.S. 2011. Compatible weighting method with rank order centroid: Maximum entropy order weighted averaging approach. European Journal of Operational Research 212: 552-559. 
Aylin, P., Yunus, A. \& Bottle, A. 2010. Weekend mortality for emergency admissions. A large, multicenter study. QualSaf Health Care 19: 213-217.

Azmi, S.Z., Latif, M.T. \& Ismail, A.S. 2010. Trend and status of air quality at three different monitoring stations in the Klang Valley, Malaysia. Air Quality Atmosphere and Health 3: 53-64.

Barron, F.H. \& Barret, B.E. 1996. Decision quality using ranked criteria weights. Management Science 429(11): 1515-1523.

Bottle, A., Aylin, P. \& Majeed, A. 2006. Identifying patients at high risk of emergency hospital admission: A logistic regression analysis. J. R. Soc. Med. 99: 406-414.

Caley, M. \& Sidhu, K. 2010. Estimating the future healthcare cost of an aging population in the UK: expansion of morbidity and the need for preventive care. J. Public Health 33(1): 117-122.

Chena, R., Chub, C. \& Tanc, J. 2010. Ambient air pollution and hospital admission in Shanghai, China. Journal of Hazardous Materials 181: 234-240.

Choi, J.H., Xu, Q.S. \& Par, S.Y. 2007. Seasonal variation of effect of air pollution on blood pressure. J. Epidemiol. Commun. Health 61: 314-318.

Cram, P., Hillis, S.L., Barnett, M. \& Rosenthal, G.E. 2004. Effects of weekend admission and hospital teaching status on inhospital mortality. Am. J.Med. 2(117): 151-157.

Dominick, D., Juahir, H., Latif, M.T. \& Zain, S.M. 2012. Spatial assessment of air quality patterns in Malaysia using multivariate analysis. Atmospheric Environment 60: 172-181.

Friger, M., Yackerson, N., Bolotin, A. \& Kordysh, E. 2006. Meteorological factors influence on hospitalization for respiratory diseases and symptoms in the South Israel. Epidemiology 17: 423-424.

Hamilton, P., Eschiti, V.A. \& Hernandez, K. 2007. Differences between weekend and weekday nurse work environments and patient outcomes: A focus group approach to model testing. J. Perinat. Neonatal. Nurs. 21: 331-341.

Hermans, E., Bossche, F.V. \& Wets, G. 2008. Combining road safety information in a performance index. Accident Analysis and Prevention 40: 1337-1344.

Hermans, E., Ruan, D., Brijs, T., Wets, G. \& Vanhoof, K. 2010. Road safety risk evaluation by means of ordered weighted averaging operators and expert knowledge. Knowledge-Based Systems 23: 48-52.

Hwang, C.L. \& Yoon, K. 1981. Multiple Criteria Decision Making: Methods and Applications. New York: Springer.

Jackson, J.L., Chamberlin, J. \& Kroenke, K. 2001 . Predictors of patient satisfaction. Soc. Sci.Med.52: 609-620.

Jalaluddin, B., Morgan, G. \& Lincoln, D. 2006. Association between ambient air pollution and daily emergency department attendances for cardiovascular disease in the elderly (65 years), Sydney Australia. J. of Exposure Science and Environmental Epidemiology 6: 225-237.

Kan, H., London, S.T. \& Chen, G. 2008. Season, sex, age, and education as modifiers of the effects of outdoor air pollution on daily mortality in Shanghai, China: The public health and air pollution in Asia (PAPA) study. Environ. Health Perspect. 116: 1183-1188.

Liang, W.M., Wei, H.Y. \& Kuo, H.W. 2009. Association between daily mortality from respiratory and cardiovascular diseases and air pollution in Taiwan. Environ. Res. 109: 51-58.

Mahiyuddin, W.R., Sahani, M. \& Aripin, R. 2012. Short-term effects of daily air pollution on mortality. Atmospheric Environment 65: 69-79.
Martin, G., Keller, C.P. \& Foster, L.T. 2012. Constructing a composite adolescent health and wellness index for British Columbia, Canada using a spatial multi-criteria analysis approach. Child. Ind. Res. 5: 215-234.

Maznah, M.K. 2008. Determination of Criteria Weight. Bangi Selangor, Malaysia: Universiti Kebangsaan Malaysia.

Maznah, M.K. \& Jemain, A.A. 2012. Involvement of panel of evaluators in aggregating subjective rank based values to solve multi-criteria problems. Sains Malaysiana 41(3): 353-360.

Ministry of Health Malaysia. 2009. Annual Report 2009.

Nik Azman, NAM. 2010. Malaysia Quality of Life. Economic Planning Unit, Prime Minister's Department, Malaysia.

Noh, J. \& Lee, K.M. 2003. Application of multiattribute decisionmaking methods for determination of relative significance factor of impact categories. Environmental Management 31(5): 663-641.

Omar, N.Y.M.J., Abas, M.R.B., Ketuly, K.A. \& Tahir, N.M. 2002. Concentrations of PAHs in atmospheric particles (PM-10) and roadside soil particles collected in Kuala Lumpur, Malaysia. Atmospheric Environment 36: 247-254.

Organisation for Economic Co-Operation and Development (OECD). 2008. Handbook on Constructing Composite Indicators: Methodology and User Guide.

Ostro, B., Roth, L., Malig, B. \& Marty, M. 2009. The effects of fine particle components on respiratory hospital admissions in children. Environmental Health Perspectives 117: 475-480.

Peng, R.D., Dominici, F. \& Pastor, B. 2005. Seasonal analyses of air pollution and mortality in 100 US cities. Am. J. Epidemiol. 161: 585-594.

R Development Core Team. 2009. A Language and Environment for Statistical Computing. Austria, Vienna: R Foundation for Statistical Computing.

Ren, C. \& Tong, S. 2006a. Temperature modifies the health effects of particulate matter in Brisbane, Australia. Int. J. Biometeorol. 51: 87-96.

Saaty, T.L. 1980. The Analytic Hierarchy Process. New York: McGraw-Hill.

Saisana, M. \& Tarantola, S. 2002. State-of-the-art Report on Current Methodologies and Practices for Composite Indicator Development. Joint Research Centre.

Schwartz, J., Samet, J.M. \& Patz, J.A. 2004. Hospital admissions for heart disease: The effects of temperature and humidity. Epidemiology 15: 755-761.

Shao, L., Luo, M. \& Walker, R. 2008. Impact of hot weather conditions on respiratory and cardiovascular hospital admissions in New York City, USA. Epidemiology 19: 302-303.

Silverman, B.W. 1986. Density Estimation for Statistics and Data Analysis. London: Chapman and Hall.

Stafoggia, M., Schwartz, J. \& Forastiere, F. 2008. Does temperature modify the association between air pollution and mortality? A multicity case-crossover analysis in Italy. Am.J. Epidemiol. 167: 1476-1485.

Yi, O., Yun-Chul, H. \& Ho, K. 2010. Seasonal effect of PM10 concentrations on mortality and morbidity in Seoul, Korea: A temperature-matched case-crossover analysis. Environmental Research 110: 89-95.

Zeleny, M. 1982. Multiple Criteria Decision Making. New York: McGraw-Hill.

Zhou, P., Fan, L.W. \& Zhou, D.Q. 2010. Data aggregation in constructing composite indicators: A perspective of information loss. Expert Systems with Applications 37: 360-365. 
Nor Hasliza Mat Desa* \& Maznah Mat Kasim School of Quantitative Sciences

Universiti Utara Malaysia (UUM)

06010 Sintok, Kedah D.A.

Malaysia

Abdul Aziz Jemain

School of Mathematical Sciences

Faculty of Science \& Technology

Universiti Kebangsaan Malaysia

43600 Bangi, Selangor D.E.

Malaysia
*Corresponding author; email: nliza@uum.edu.my

Received: 19 December 2013

Accepted: 11 August 2014 